\title{
JOHN HUTCHINSON IN AUSTRALIA AND FIJI
}

\author{
by
}

\author{
BRYAN GANDEVIA*
}

\section{WHEREABOUTS UNCERTAIN}

JOHN HUTCHINSON, described as "surgeon", was one of seven cabin passengers who left London in September $1852^{1}$ on the first Australian voyage of the Washington Irving (900 tons, Captain John Jones). ${ }^{2}$

The voyage was recorded as "without untoward incidents and very pleasant" although one of approximately 270 intermediate and steerage passengers (including about fifty children) hanged himself in a fit of despondency. But excitement and tension must have mounted as the ship negotiated the dangerous heads to Port Phillip Bay and sailed to a crowded anchorage close to Melbourne on 11 December 1852. News of the startling gold discoveries in Victoria in 1852 had already created a migratory wave from England, for the most part of young, healthy, single men. In 1852, Dr. Hutchinson was but one of 45,000 arrivals from England amongst a total from all sources of nearly 80,000 , which almost doubled the population of the district. Unfortunately, we know nothing of his impressions of the disorganized, turbulent, flamboyant and insanitary Melbourne during its dramatic period of transition from a village not two decades old to the "Queen city of the South". What were his reactions to the extortionate costs of landing and transporting his luggage to lodgings remarkable more for their rental than their comfort and service, or to the realization that his sterling pounds were transferable into local currency only at a discount of twenty per cent? Was he startled by the waterfront "Rag Fair", where disillusioned new arrivals sold their few possessions to raise the capital necessary to get them to the diggings, or appalled by the hasty development of Canvas Town, close to Prince's Bridge, housing several thousands of his fellow migrants for a week or so whilst they organized their resources?

*Bryan Gandevia, M.D., F.R.A.C.P., Associate Professor of Thoracic Medicine, University of New South Wales Department of Medicine, The Prince Henry Hospital, Sydney, Australia 2036.

\footnotetext{
1 Melbourne, Argus 13 December 1852; La Trobe Library, index of arrivals in 1852; W. J. Biddle, index of shipping, La Trobe Library. Hutchinson's age is wrongly given as twenty-nine but there can be no doubt of his identity; the date of departure is as given in his obituary notice (Med. Times Gaz., 22 February 1862, p. 201) and no other John Hutchinson arrived (unless as an unrecorded steerage passenger) until after July 1853.

2 The first ship built by the famous Donald McKay, of Boston, in 1845, the Washington Irving was on the trans-atlantic run until sold to Marshall \& Eldridge of London for use in the expanding Australian trade. Her measurements were $151 \times 33 \times 21$ feet, but possibly some alterations were made as her registered tonnage was 751 tons, whereas the Argus gives 900 tons (the late Charles Bateson, personal communication).

It is impossible to convey in a few sentences the phenomenal impact of the gold discoveries on the infant colony. See G. Serle, The Golden Age, Melbourne University Press, 1963; G. Blainey,
} 


\section{Bryan Gandevia}

Whether or not "gold fever" was the motive for Hutchinson's departure from England, it seems possible that he became a victim, for there is no record of him in Melbourne or elsewhere for almost two years. Bendigo (or Sandhurst as it was known for a time) was the site of exciting "finds" shortly before his arrival, and it would be natural enough if he followed the example of other gentleman visitors in making a tour of the goldfields, and perhaps, in view of his geological and mining experience, even "trying his luck". At all events, he later settled in Sandhurst, and like many another doctor, found it expedient (and probably more profitable) to resume medical practice.

That Hutchinson spent some time in Melbourne is evident from his own statement in 1855 from Sandhurst that "I like these quarters much better than in Melbourne". Between June and December 1854 he acted as one of the two honorary secretaries to the Commissioners appointed to prepare Victoria's contribution to the Paris Exhibition of 1855, exhibited in Melbourne prior to its departure. The exhibits included two by Hutchinson: skulls and skeletons of aborigines (which suggests a visit to the interior), and a specimen of crochet work (which at least confirms the breadth of his interests). ${ }^{5}$

On 8 August 1854 he was proposed as a member of the newly-formed Philosophical Society of Victoria by its first Treasurer, Dr. David Wilkie, a leader of the medical profession and a prominent citizen of Melbourne. He was immediately elected (in absentia) to the interim Council of the Society to hold office until August 1855. The Society described itself in its prospectus as "embracing the whole field of science, with a special reference to the cultivation of those departments that are calculated to develop the natural resources of the country"; it was also to foster the development of a national museum. In many respects, including three categories of fellows, honorary and ordinary members, it seems that the organizers had in mind an ambitious colonial model of the Royal Society. One of its first acts was to seek the active support of its patron, the Lieutenant Governor, Sir Charles Hotham, and to this end it appointed a deputation comprising the President (Captain, later Sir, Andrew Clarke, then Victorian Surveyor-General), Dr. Solomon Iffla, and Dr. John Hutchinson. Hutchinson's appointment to this important task force, also made in his absence, indicates his standing in the eyes of Council, and possibly suggests that for some reason his presence might have carried weight with the Governor. However, Sir Charles declined to meet the deputation in view of the overall insufficiency of public funds

The rush that never ended, Melbourne University Press, 2nd ed., 1969; H. G. Turner, A history of the colony of Victoria, vol. 1; 1797-1854, London, Longmans Green, 1904; facsimile ed., Melbourne, Heritage Publications, 1973.

- Letter from Hutchinson to Stawell, 2 November 1855 (see text, below).

- J. A. Panton, a senior government officer in the Bendigo goldfields and an Exhibition commissioner, refers to meeting Hutchinson in his 'Reminiscences', La Trobe Library, MS. 7727, in which he also records a variant of the case of Dr. Wall (see below). The Catalogue of the Melbourne (later Paris) Exhibition, 1854 (La Trobe Library) lists the Commissioners drawn from politics, public service, law and science, the latter group including Ferdinand Mueller, the famous botanist, and Sir James Palmer, editor of John Hunter's collected works (4 vols., London, Longman, [1835]-37) but currently Speaker of the Victorian Legislative Council. The colony's chief medical officer, William McCrae, with whom Hutchinson later corresponded, was also one of the nineteen commissioners appointed by the Lieutenant-Governor. 


\section{John Hutchinson in Australia and Fiji}

and his belief that the colony's gold and coal resources were already being adequately investigated; he indicated qualified support "at a future time". Hutchinson did not attend any Council or ordinary meetings of the Society, he never contributed to its journal, and when it merged with the Victorian Institute for the Advancement of Science in July 1855 to form the Philosophical Institute (later the Royal Society of Victoria), his name disappeared from the membership lists. ${ }^{\circ}$

It is strange that Hutchinson did not join the Geological Society, founded in 1853, nor contribute at any time to its proceedings. More remarkable is his failure to join the Victorian Medical Association; Dr. Wilkie was the first President in 1852-1853, another councillor of the Philosophical Society, Dr. Richard Eades, succeeded him, and Dr. Iffla was also a member. Eades was also a foundation member of the MedicoChirurgical Society established in the same year. It is unbelievable that Hutchinson was not invited to address these groups, nor their successor, the Medical Society of Victoria, and one must assume that he declined." Certainly, he did not practise medicine in Melbourne.

In the light of much later events, it is of interest that Sigismund Wekey, a turbulent refugee from Hungary after the uprising of 1848 , controversial secretary of the Philosophical Society and a student of the goldfields, apparently failed to inveigle Hutchinson into one of his unsuccessful speculations in 1854; Drs. Eades and Iffla became directors of Wekey's short-lived Victorian Vineyard and Fruit Garden Company, but not Dr. Hutchinson. ${ }^{8}$

According to his obituary notices, Hutchinson had wide cultural interests but no record that he participated in any such activity has been found in Melbourne. He did not join the Victorian Society of Fine Arts, nor contribute to its first exhibition (1856) of the work of some forty local artists. The major Australian art galleries and archives have no works by Hutchinson, although three excellent watercolours of Sandhurst in the 1850 s by an unknown artist are held by the National Library. The records of the Philharmonic Society in Melbourne have not survived.

- R. T. M. Pescott, 'The Royal Society of Victoria from then, 1854, to now, 1959', Proc. Roy. Soc. Vic., 1961, 73: 1; Trans. Phil. Soc. Vic., 1855, 1: vii-ix. The original minutes of both Council and ordinary meetings, now in the possession of the Royal Society of Victoria, provide no additional information beyond confirming Hutchinson's non-attendance.

The development of these active societies at this period reflects the fact that the doctors were beginning to accept the colony as their permanent home, and hence they found a need for "continuing education". Hutchinson's failure to contribute during eight years in the colony must be viewed against this background. The remarkable work of these medical groups is reviewed by $\mathbf{H}$. Boyd Graham, 'Happenings of the now long past: the centenary of the Medical Society of Victoria', Med. J. Aust., 1952, 2: 213.

- Biographical details concerning Wekey (originally Vekey) are given by E. F. Kunz, Blood and gold: Hungarians in Australia, Melbourne, Cheshire, 1969, pp. 100-105. Clarke and Eades are listed in Australian dictionary of biography, Melbourne University Press, 1966-1974, vols. 3 and 4 respectively. Notes on Iffla are given by K. M. Bowden, Doctors and diggers on the Mount Alexander goldfields, Melbourne, the author, 1974, p. 202. For Wilkie, see H. Boyd Graham, 'The Honourable David Elliot Wilkie, M.D., a pioneer of Melbourne', Med. J. Aust., 1955, 2: 585. A detailed contemporary account of the Bendigo district in which Hutchinson ultimately settled is given by W. Howitt, Land, labour and gold, fascimile ed., Sydney University Press, 1972 (2 vols. in 1), vol. i, p. 372ff. and vol. ii, p. 46ff. Howitt, an honorary member of the Philosophical Society, was almost certainly known to Hutchinson; his brother was Dr. Godfrey Howitt, chairman of the Medical Board of Victoria. 


\section{Bryan Gandevia}

AT SANDHURST (BENDIGO)

It is refreshing to move to a period of Hutchinson's life about which more positive information is available. During 1855 he presented his qualifications to the Medical Board of Victoria (Dr. Godfrey Howitt, a colleague of Hutchinson's on the Council of the Philosophical Society and the Exhibition Commission, was chairman of the Board) and became a legally qualified medical practitioner in the colony of Victoria. Prior to 1862 this step was not essential to practice but it gave standing and respectability; Hutchinson would have known of the widespread unqualified practice in the goldfields, and he may well have been aware that the recently formed Bendigo Medical Association had approached the Victorian Medical Association for its support in taking action against the innumerable quacks. ${ }^{\circ}$ On 22 September 1855 an advertisement in the Bendigo Advertiser was headed "Diseases of the Chest", and it ran: "Dr. Hutchinson M.R.C.S. Consulting Physician, Accoucheur, late physician to a leading London Hospital for diseases of the Chest and author of the Spirometer may be consulted at Mr. Jones' Chemist at Market Square, Bendigo, from 1 to 2 o'clock and at other times at the Brick Cottage, White Hills Hamlet". The advertisement appeared twice weekly with each issue until 22 December. The electoral roll for 1856-57 confirms the latter address, three miles north of Bendigo, where a brick dwelling must have been a feature amidst the tents and huts of a rich goldfield at this period. Market Square, now the site of the Town Hall, boasted a newspaper, a surgeon dentist, blacksmith, piano-maker, and restaurateur, in addition to the distinguished London consultant. He became a "consulting medical officer" to the Bendigo Gold District Hospital in 1859, but played no active role in the hospital's affairs. Perhaps, as his advertisement suggests, and as a Bendigo acquaintance explicitly states, he did practise strictly as a consultant, although such restricted practice was virtually unknown, even in the cities. ${ }^{10}$

Dr. Keith Bowden's detailed study of doctors on the goldfields of this region 11 throws much light on Hutchinson's activities over the next few years; they chiefly reflect Hutchinson's interest in forensic medicine. The first case in which he was involved, late in 1855, was of a miner with a bullet in his neck following a dispute on his claim. J. E. Wall, an unqualified practitioner but with five years' experience as an apprentice, called on Hutchinson's assistance when it was found that swallowed fluids continued to emerge through the wound in the neck, and surgical emphysema was also persisting. Hutchinson regarded removal of the bullet as vitally important, but after an hour's search with probes and forceps he was unable to extract it; Wall then did so in about ten minutes. Considering nourishment of the patient equally critical, Hutchinson tried on two occasions to introduce a stomach tube without

\footnotetext{
- Letter from Dr. Allison, secretary to the Bendigo Medical Association, "enclosing resolutions passed at a General Meeting relative to unlicensed practitioners and Chemists ..." and addressed to the Victoria Medical Association. The Association, which included Wilkie, Eades and Iffla, presumably known to Hutchinson, promised its "hearty cooperation". Victoria Medical Association minutes, 1 April 1854 (Museum, Medical Society of Victoria).

${ }^{10}$ Hospital Committee minutes, 27 January 1859. There is no further reference to Hutchinson in the hospital's records, and no newspaper reference has been found to his taking part in relevant public meetings. Panton, op. cit., note 5 above, states that Hutchinson came "to practice only as a consulting physician".

11 Bowden, op. cit., note 8 above.
} 


\section{John Hutchinson in Australia and Fiji}

success. Wall said at the inquest that he had asked Hutchinson to desist because the patient was nearly suffocating, and that Hutchinson, believing all risks justifiable, had advocated chloroform to help allow passage of the tube. According to Hutchinson, Wall's idea of nourishment was "a door mat of raw beef placed on the man's middle, and he was supposed to derive nutriment from it through the porous skin"; ${ }^{12}$ on Hutchinson's advice this approach was changed to one of enemas and fomentations of beef tea, with steak to suck and sips of wine or chocolate. Hutchinson recognized the presence of left-sided chest complications, a diagnosis from which Wall differed, so that Hutchinson's recommended local blistering and general purging were not carried out. Hutchinson said at the inquest that any medical student should have been aware of pneumonia and empyema, from which, combined with starvation, the unfortunate digger died a month after his injury. Autopsy confirmed these findings, as well as injury to the oesophagus and trachea. Hutchinson emerges as diagnostically and theoretically supreme but therapeutically somewhat ineffectual, although the circumstances may have been adverse. The coroner, a legally qualified medical practitioner, committed Wall for trial on a charge of manslaughter. Hutchinson, self-confident and aggressive as he was to appear on other occasions, took the remarkable step of writing two letters, one to the Attorney-General of Victoria, William (later Sir William) Stawell, and one to the President of the Medical Board, Dr. W. McCrae (both, incidentally, members of the Philosophical Society). These letters deserve quoting in full not only for their content but for the strange manner of their expression:

To Stawell Esq.

White Hills

Attorney General

Bendigo

Melbourne

2 Nov 1855

My Dear Sir,

I am happy of any opportunity to write to you - but on this occasion it is somewhat particulous. There has been a long case of inquest here-on the body of Lawrence shot by Northam which took some five days of inquiry which was done by Roach* [sic] with great patience and skillin it J. E. Wall-alias Dr. Wall is committed for manslaughter chiefly on my evidence. Now I particularly wish to draw your attention to the case. Our Diggins [sic] swarm with illegally qualified men. This case I hope to make an example of. You have no law for these men but such as now turns up**-I particularly wish your attention because I know you show no quarter to what is illegal and as such I draw your attention to it-when I gave evidence at Castlemaine in the case-great credit is due to Roach in the matter. I like these quarters much better than Melbourne-I shall be glad to see you again.

Direct, care of

James Trous, Black Swan,

Believe me

My dear sir

I remain yours truly

Bendigo.

John Hutchinson

12 Panton, op. cit., note 5 above. The rest of the case report, divested of medico-legal argument and expressed in modern terminology, is summarized from Bowden, op. cit., note 8 above, pp. 134-139.

*The correct spelling of the coroner's name was Roche.

**The unqualified practice of medicine was not in itself illegal, and Hutchinson probably means that the main chance of successful prosecution arose in the case of death. Even so, the test often applied was whether the attendant had made himself "master of the case", a difficult test even today! 
White Hills

Bendigo

26 Nov 1855

Dear Sir,

A very important trial is to come off on the 10th of next month at Castlemaine-Northam for the murder of Lawrence-wherein I am an important witness in charging a certain unqualified man Dr. Wall with ignorant treatment-and so he stands his trial for Manslaughter. At the same time-I here enclose you a placard of this man wherein he states that his partner Jordan is a Member of the Victoria Board-which I believe not to be the case, if he is not a memberno doubt he will be subject to you for thus pretending. Now as both Wall and Jordan will come under Stawell I send this for you to ascertain if Jordan is a member, as he states, of your board if not tell Stawell of it. Wall's case is a most flagrant case of gross neglect. I am taking great pains to draw some diagrams for the Jury that they may understand the case as clear as possible. The trial will be very curious.

I do not regret at having left Melbourne-present my compliments to your lady, more another time.

Dr. McCrae

John Hutchinson

[A note on the letter states that Jordan was not a member of the Victorian Medical Board, that is, he had not become registered as a legally qualified medical practitioner].

Wall was acquitted and Hutchinson did not give evidence, but later he had to take legal action to recover some textbooks which he had lent Wall at the time of Lawrence's illness. ${ }^{13}$

In 1856, an intoxicated James Smith died four days after a blow (from a loaded hammer-headed whip) on the left side of his head whilst maliciously damaging property. ${ }^{14}$ The coroner's autopsy was attended by Hutchinson, on his own statement, "out of interest"; it proved so interesting that he retained and cleaned the fractured pieces of temporal bone, subsequently producing them at the inquest. Smith's attacker was committed for trial on a charge of manslaughter but was acquitted, essentially on the grounds of self-defence. The defendant's counsel expertly cross-examined Smith's medical attendant (who incidentally had performed the autopsy) with the object of showing that the fracture should have been diagnosed before death and that the fragments of bone should then have been elevated; by implication, Smith's death was not solely his client's responsibility. Hutchinson did not give evidence but Bowden suggests on reasonable grounds that he helped prepare the expert cross-examination. Hutchinson wrote again to the Attorney-General-at least on this occasion he wrote after the trial-complaining that the temporal bone fragments were not available as an exhibit at the trial, hinting that the coroner had withheld them to avoid criticism of the attending doctor's management. Hutchinson clearly believed that operation to relieve compression should have been carried out. He argues in general that traumatized organs should be just as essential to court proceedings as the instruments producing the trauma. The argument is rational but the circumstances strange, and the letter is again diffuse and ill-expressed. Following a very similar case of fractured skull, in which the responsible surgeon was committed for trial "for a do-nothing treatment", two anonymous letters appeared in the Bendigo Advertiser, one of which drew attention to the apparent anomaly whereby the doctor treating Smith for a

18 Ibid., p. 137.

14 Similarly summarized from ibid., pp. 148-153. 


\section{John Hutchinson in Australia and Fiji}

similar condition had not been committed. The second letter also advocated early operation, and it seems likely that one or both were written by Hutchinson. ${ }^{15}$

Hutchinson appears at his forensic best in the remarkable case of the murder of Martin Loemen by his partner, Christian Von See, so much so that his deposition relating to the autopsy findings is reproduced in full (Appendix 1). Although this case became a Victorian cause celèbre, the general pattern is not rare in the colonial history of the time. Loemen and Von See, who were known to have argued frequently and bitterly, set off on a wide search for a lost horse in June 1858. Von See alone returned eight days later, with the story that Loemen had sent him back and gone on by himself. Loemen's de facto wife soon reported his disapperance to the police, and a bloodstained hatchet, bag and shirt were found on the premises which she shared with the two men. Other circumstantial evidence raised suspicion, and in July Von See was detained. In August, seven weeks after Loemen's disappearance, a body was found in the bush by a shepherd, partly burned and dismembered, with signs that "wild dogs or birds had been eating it". Some clothing remnants and other items were also found. For the inquest, the skeleton was laid out on a board, the head separated from the body, and from his deposition one can visualize Hutchinson demonstrating his points to the jury with the éclat of a medieval anatomist. In particular, attention was drawn to the bizarre growth of hair, as thick as on a man's head, on a piece of skin from the left leg. This was one of the features which enabled Loemen's mistress, carrying their child, to identify the remains. Hutchinson's evidence indicated that he had spent days studying the material, and he produced the results of experiments with hatchet blows on a piece of wood to support his contentions. The defendant's counsel was later to describe Hutchinson's evidence as "the fanciful deductions of a speculative surgeon", but unsuccessfully; in November Von See was the last, or one of the last, criminals to be publicly hanged in Victoria, and gruesome accounts are on record of the four minutes which he took to die. Whilst Hutchinson's evidence may be questioned at several points (the age estimation and time since death, for example), Bowden, himself a former forensic pathologist, concedes that it was masterly for the times. A local newspaper correctly went further: Hutchinson's evidence exhibited "an amount of patient and scientific investigation and logical deduction which has scarcely a parallel in the annals of colonial medical jurisprudence."16

In September 1856 a letter signed "Vox" in the Bendigo Advertiser referred indirectly to the "deplorable state of mental capacity" of six citizens who had positively identified the corpse of a Bendigo man found drowned in Port Phillip Bay. Vox went on to say that six men "of common sense might have examined the disputed body" thoroughly, and measured height and weight, taken hair, photographs, and a facial cast, and made other explicit observations; without such data most people, said Vox, would continue to dispute the identification. However, one of the six, Dr. James Boone, an American

15 Bendigo Advertiser, 29 August 1856, quoted by Bowden, op. cit., note 8 above, p. 159.

16 Ibid., pp. 167-172; Argus, 30 November 1858. The deposition (appendix) is quoted from Victorian Public Records Office, Briefs, Supreme Court Records, (Uhl Index), Criminal Sessions 3-131-21. The deposition has been taken by a clerk but Hutchinson's characteristic signature is appended. 


\section{Bryan Gandevia}

graduate, had a record of his former patient's scars and had carefully noted that those on the body tallied with his record. Another of the six men of suspect intellectual ability, Daniel Prothero, took firm and direct action. Failing to obtain satisfaction from the editor as to the authorship of the letter, Prothero stormed out of the Advertiser office, went up to Dr. Hutchinson standing outside the Shamrock Hotel, and demanded to know if he had written the letter in the newspaper, which he waved. Hutchinson replied that if his name was attached to it, he had, but if not he declined to answer a stranger, whereupon the forthright Mr. Prothero grasped the doctor by the neck and tore his beard out. Hutchinson won the ensuing case of assault, but lost the sympathy of an enraptured audience which saw Prothero produce the beard from his pocket, carefully wrapped in tissue paper, and offer it back to Hutchinson with the suggestion that it could be replaced by "Professor Sands", a local barber, for a fee of $8 d$. Much to the annoyance of the Advertiser, sympathizers contributed a shilling each to pay Prothero's fine of ten pounds. Nor was the mirth at Hutchinson's expense over, for Bendigo's vaudeville star made it the subject of a comic song entitled "Why don't you shave, or Prothero v. Hutchinson". Four of the ten verses ran as follows:

They one and all without hesitation, To that effect sign'd a declaration, And 'twas believed by every one, Except this Doctor Hutchinson.

He to the Advertiser wrote, His letter of course I needn't quote, But there his utmost he did try, To prove their oath was all a lie.

T' other day Mr. Prothero chanc'd to meet, This Doctor Hutchinson in the street, So he axed with a frown instead of a laugh, "Did you write that ere paragraph?"

Says Hutchinson, "Yes and what of that", Says Prothero, "I could knock you flat, But to strike such an effigy I'd be a brute", So he plucked his beard out by the root.

Bowden suggests that the reluctance to strike an "effigy" may relate to Hutchinson's alleged tuberculosis, but we have found no specific reference to support the oral tradition that he took the long sea voyage to Australia because he had phthisis. ${ }^{17}$

Hutchinson's professed interest in midwifery is attested only by his unofficial attendance at an autopsy on a girl of sixteen who had died from haemorrhage related to a partially retained placenta. A German doctor managed the fatally prolonged third stage of labour with remarkable inactivity, except, according to the girl's mother, for smoking and drinking gin on the sofa. Hutchinson did not give evidence at the inquest, and ultimately the doctor was acquitted of a charge of manslaughter. ${ }^{18}$

\footnotetext{
${ }^{17}$ Summarized from Bowden, op. cit., note 8 above, pp. 162-165. Bowden quotes the complete song, sung to the tune of Billie Vite or Nellie Green, from a copy in the La Trobe Library.

${ }^{18}$ Bowden, op. cit., note 8 above, p. 176.
} 


\title{
John Hutchinson in Australia and Fiji
}

Dr. Hutchinson's last appearance in court to our knowledge was in August 1860, when Mr. Bannerman, a bank manager, prosecuted George Lansell, a soap and candle manufacturer, for causing a public nuisance. Hutchinson was one of no less than four doctors who gave evidence against Lansell but to no avail. Hutchinson's evidence, as recorded by a clerk, is a fair sample:

\begin{abstract}
I have seen the defendant's premises in View Place. I have seen a sign board on them. I have noticed a disagreeable smell a faint and sickly smell arising from the defendant's premises On the 4 November last I was at Mr. Bannerman's house I smelt a stench on that occasion which made me feel sick There is a corner of a house which immediately you passed the corner of the smell came so strong that it made me feel sick and faint I have smelt it similarly but not so bad I have smelt it on the hill at the back of the postoffice. It is not pure air in the most mitigated form nor fresh and therefore injurious to the health of the neighbourhood I have known a patient to suffer inconvenience from the smell but I do not say ill-but if it was continued on it could be injurious. The building has been altered and the effect has been to alter the direction of the stench and send it to places where it has not reached before. . . . [In cross-examination] The stench has not been so strong on passing up View Place as it was before the alterations.
\end{abstract}

This was, of course, a period of expanding small industries in Australia, and the health hazards of their noxious effluvia were hotly debated, more on emotional grounds (as in Hutchinson's evidence) than scientific. ${ }^{19}$

Several lengthy items in the Bendigo Advertiser (13 August, 7, 8, 19, 22 September) indicate that Hutchinson was largely responsible for obtaining a reprieve for a man named Nial, convicted of murder on circumstantial evidence. In the light of fresh evidence emerging after the trial, and of alleged irregularities in the police evidence and in Dr. Roche's conduct of the inquest, Hutchinson formed a committee (including his old antagonist, Dr. Wall) which readily gained the support of local citizens. Hutchinson personally led two deputations to Melbourne to interview the Governor, the Attorney General, and the presiding judge, taking with him on one occasion signed statements from each of the jurors indicating that had the additional eviderce been available at the trial no conviction would have been recorded. Where justice was concerned, Hutchinson was ever ready to fight.

Hutchinson was "greatly excited" by the ill-fated expedition of Burke and Wills, sponsored by the Royal Society of Victoria with the aim of crossing central Australia from south to north, and "had a strong wish to make one of the courageous band of explorers, many of whom were never to return". Late in August, he visited the expedition when it crossed the Campaspe River near Bendigo on the first stage of its journey, forming one of a party of Sandhurst gentlemen who dined with the explorers in the evening. Hutchinson "very wittily and humourously proposed the health of the camels", which had aroused much curiosity and interest. The visitors, "thanks to the powerful aid of Dr. Roche . . . made a night of it-a night, not of carousing, but of fun and mischief": unfortunately no further details of this lighter side to Hutchinson's life are available. ${ }^{20}$

19 Queen v. George Lansell, Sandhurst, 13 August 1860: Public Records Office NCR 2635. On the general problem, see B. Gandevia, 'Occupation and health in Australia since 1788', Bull. Postgrad. Cttee. Med., Univ. Syd., 1971, 27: pp. 157; D. Dyason, 'The police and public health acts in the early years of the colony of Victoria', Proc. Aust. Assoc. Hist. Phil. Sci., Sydney, 1975, p. 15.

${ }^{20}$ For a recent account of the expedition, see A. Moorehead, Cooper's Creek, London, Hamish 


\section{Bryan Gandevia}

Of Hutchinson's other activities in Bendigo there is little record. He was chairman of a meeting held to encourage the establishment of a branch of the Colonial Bank, and it was he, or a medical namesake in the town, who attended a race meeting on one occasion, and contributed five shillings and sixpence to a fund for a stabbed woman. ${ }^{21}$ No record of him exists in the Victorian Mines Department, nor of the North Bendigo Gold Mine, in which he had an interest. He appears to have given no public lectures, as he did in England.

Hutchinson's departure from Bendigo is heralded by announcements in the Advertiser for 8 February 1861 that his "Geological Cabinet of the Goldfields' Formations" is for sale, and that his house at Market Square is to be sold or let. An editorial comment recommended the collection to the attention of the curators of the Mechanics' Institute. Later in February the Sandhurst Bee and the Bendigo Advertiser carried advertisements for the sale by auction of Dr. Hutchinson's house in Williamson Street (presumably near its junction with Market Square, to which he had moved in 1859), "a substantial weatherboard building of five rooms," together with the whole of his very valuable furniture, plate, paintings, etc., large and small glass cases, one case of geological specimens, a large quantity of rare curiosities, and articles of vertu ["virtue" in one paper], a very handsome self-acting pianoforte, also "a very superior chestnut mare, nearly thorough-bred", quiet in saddle and harness, and very fast, "together with a first-class buggy and harness complete". ${ }^{22}$ There is no mention of a spirometer!

The geological collection remained unsold, but subsequently it was purchased by private subscription for $£ 81$ 10s. $0 d$. and presented to the Mechanics' Institute: it was said of the Institute in 1862 that "its attractiveness [had] a short time previously been strengthened by the very valuable geological collection of the late Dr. Hutchinson". ${ }^{23}$

The Advertiser bade Hutchinson farewell on the day of the sale:

This gentleman, who has been for some time in practice in Sandhurst, and who has achieved an European reputation as the inventor of the spirometer, and another of an elaborate work on lung diseases, leaves the district this morning en route for the Fiji Islands, where, we understand, he is about to turn the amputating knife into a shepherd's crook. We wish Dr. Hutchinson success in his new undertaking.

And so Hutchinson set out on the 100-mile coach journey to Melbourne. Although he missed the peak of the alluvial mining in the first two years of Bendigo's existence,

Hamilton, 1963. The quotations are from the Bendigo Advertiser, 16 November 1861 and 30 August 1860 respectively.

21 Bowden, op. cit., note 8 above, p. 137; Bendigo Advertiser, 10 December 1856 and 9 March 1857.

22 Sandhurst Bee, 22, 23, 25 and 26 February 1861; Bendigo Advertiser, 26 February 1861. The sale took place on Tuesday, 26 February, but some of the advertisements may have confused intending buyers by referring to Tuesday 27 February. However, on the following day the sale purchasers were formally requested to clear all goods bought by four o'clock "this day" (Sandhurst Bee, 27 February 1861).

22 G. Mackay, The history of Bendigo, Bendigo, Mackay, 1891, p. 151; Bowden, op. cit., note 8 above, p. 132; the Bendigo Institute of Technology, formerly the Sandhurst Mechanics' Institute, believes that its specimens include Hutchinson's collection, but the items are not individually identifiable (Mr. A. Craig, Vice-Principal, by courtesy of Dr. J. Gault). 


\section{John Hutchinson in Australia and Fiji}

he had seen the establishment of the deep quartz mines, with their crushing batteries and the production of perhaps 2,000,000 ounces of gold. Had he stayed longer, and used his spirometer, he might have anticipated the fourfold increase in mortality among Bendigo miners from "phthisis" and "chronic bronchitis" in the last quarter of the century. ${ }^{24}$

\section{LAST DAYS IN FIJI}

On 9 March 1861, Dr. Hutchinson (his age now noted incorrectly as fifty-nine) sailed with twelve other passengers, all single men and all but one in their twenties, for Fiji on the schooner Friends, appropriately distinguished by her "male bust figurehead". ${ }^{25}$ The visit may not have been his first, or more likely he had merely had the project in mind for some time ${ }^{26}$ but in any case Australian interest in Fiji at this time was increasing. Strong rumours had been current from 1858 that Fiji was to become a British dominion, the British consul there had returned to England to advocate acceptance of the offer of cession made by a Fijian chieftain, and in 1860 a cautious government in London had sent out a special commissioner, Colonel W. J. Symthe, to report on the problems involved in annexation. ${ }^{27}$ Hutchinson arrived before the commissioner's departure late in May 1861, and was thus probably aware that Smythe's report to Lord Newcastle was not in favour of annexation. He would also have learned that the Fijians did recognize a form of land ownership at the disposal of the chiefs, and that the consul had laid down certain procedures relating to land transactions designed to ensure understanding on the part of the vendors, and hence security of tenure for European purchasers. ${ }^{28}$

24 The first studies of miners' chest complaints and of mine ventilation were conducted in Bendigo by W. Summons in 1906 following public concern expressed chiefly in the Advertiser: B. Gandevia, 'The Australian contribution to the history of the pneumoconioses', Med. Hist., 1973, 17: 368-379.

${ }^{25} \mathrm{La}$ Trobe Library, shipping records. The Friends was a single-deck carvel-built schooner belonging to a Melbourne merchant, W. J. Harris; she was launched on the Thames in 1825, and first registered in Victoria in 1857 (the late Charles Bateson, personal communication).

${ }^{26}$ Bowden, op. cit., note 8 above, p. 130 , notes that on one occasion, possibly in the case of Loemen, a deputy was appointed to assist Hutchinson because the latter might be going to Fiji. A prior visit appears unlikely in the light of Hutchinson's letter to the Bendigo Advertiser, 5 July 1861 . No likely record of an earlier visit has been found in La Trobe Library shipping records nor in Sydney departures as recorded in the Sydney Morning Herald. Dr. McGrath, a colleague of Hutchinson's at Castlemaine near Bendigo, had earlier visited and acquired land in Fiji, and this must have been known to Hutchinson (K. Bowden, personal communication).

"C. C. Eldridge, "The Imperialism of the "Little England era": the question of the annexation of the Fiji Islands, 1858-61', N. Z. J. Hist., 1967, 1: 171; Mrs. Smythe, Ten months in the Fiji Islands, with an introduction and appendix by Colonel W. J. Smythe, Oxford, H. \& J. Parker, 1864, pp. 20 and 204; R. A. Derrick, A history of Fiji, Suva, Printing Department, 1946, vol. i, pp. 144-146; W. T. Pritchard, Polynesian reminiscences .... London, Chapman \& Hall, 1866, p. 253. Pritchard, the British Consul in Fiji, is said to have incurred the displeasure of the Governor of New South Wales by publishing letters and advertisements in Sydney newspapers advocating land purchase in Fiji, but we have not located an example. Victorian interest is indicated by news items in the Argus (Melbourne) of 28 March and 24 May 1860. The white population in Fiji had recently increased to 200, partly as a result of migration of a "superior class" from Australia and New Zealand, misled by information in colonial journals (Smythe, op. cit., p. 204); many returned disillusioned. Most of the white inhabitants of Levuka had "fallen to a lower level" than the natives, and scenes of drunkenness and rioting were common (ibid., pp. 204 and 210).

20 Pritchard, op. cit., note 27 above, p. 243. On the legal aspects, see R. Else-Mitchell, 'Territorial conquest-Phillip and afterwards', Vict. hist. J., 1975, 46: 429. 


\section{Bryan Gandevia}

Whatever the risk, Hutchinson lost little time in seeking land. He appears to have been preceded in Fiji by one of his partners, J. A. C. Hunter, gentleman, of Geelong, Victoria. The third partner was Thomas Clark, an English solicitor living in Melbourne. An American local agent, Samuel Avery St. John, was employed, with Daniel Whippy (a well-known name locally to this day) as interpreter. On 15 June, a deed of sale was concluded:

Know all men, by these Presents, that we, Tawake, (Chief and Land Owner) and undersigned landowners of the property herein-after described ... for and in consideration of Thirty Muskets, Fifty pounds of powder, Two pigs of Lead, Four pieces of Cloth, six axes, six iron pots, Twentyfour knives, one thousand fish-hooks, two arm chests, in all valued at the sum of Four hundred and sixty five dollars ... do hereby sell, convey, remise, release and forever quit claim . . . all that tract or parcel of Land situate upon the Island of 'Viti Levu'* and in the district of ' $\mathrm{M}$ 'Ba' [there follows a detailed description of an area of about 15,000 acres] . . . And we do hereby acknowledge that this Instrument or Deed has been fully and correctly interpreted to us, and that we fully understand the meaning of it, and the terms of sale.

In witness whereof, Tawake and two other native chieftains signed their marks. The other signatories were Daniel Whippy (his mark), St. John, and James Laing, who had arrived on the Friends with Hutchinson. The British Consul, W. T. Pritchard, appended a document dated the previous day which certified that he had personally interviewed Tawake, who acknowledged and guaranteed ownership of the land described. Tawake also reassured the consul that he had absolute power to dispose of it, and had secured the agreement of his subordinate chiefs, his brothers and heirs. ${ }^{20}$

The circumstances of the sale were recalled before the Lands Commissioners twenty years later by St. John:

I remember the purchase of this block of land. . . I negotiated the purchase. The object of the purchase was to form a sheep run ... Messrs. J. \& L. Hunter, Laing, D. Whippy Jnr. and I came down in Whippy's vessel "Albatross"... . On our way down we met Tawake near Nacilau Point [he was fishing on the reef accompanied by friends in a canoe when St. John hailed him]. We hove to and he came on board. We stated our business. He expressed willingness to sell. He came on shore with us at Nacilau Point. ... After a time we mounted the crown of the hill above Nacilau point to see the limits of the land. ... We then followed along the crown of the range, i.e., westerly direction ... until we could see the Teidamu River, which is the lower, or western boundary. ... I I took down the description at the time. . . . I drew the deed that afternoon-the boundaries therein are those given me by the natives. ... The trade was paid in my house at Levuka. ... After execution of the deed I took Tawake and his son to Levuka to get his trade. . . . I had before been instructed by Pritchard as to the correct procedure in land purchases.

St. John carried out his task well, for the land was occupied peaceably for a decade before some relatively minor disputes occurred, and the Lands Commission ultimately accepted the validity of the transaction..$^{30}$

*Viti Levu is now the main island of Fiji on which the capital Suva, is situated. Nadi, the international airport, is about 30 miles from the land purchased. At the time, Levuka, on the adjacent island of Ovalau, was the headquarters of European activity in Fiji.

29 National Archives of Fiji: Registrar-General's Department British Consul for Fiji and Tonga Register of Deeds, 1858-1873, vol. 1, no. 109ff.

${ }_{20}$ National Archives of Fiji: Records of the Lands Titles Commission, No. 1041: St. John's evidence was given on 18 May 1881 . 


\section{John Hutchinson in Australia and Fiji}

But Hutchinson's name was missing from the list of those who inspected the proposed purchase. Perhaps he was present with Mr. Hunter "and several others who are now dead" when the "trade" was handed over at Levuka, but it seems more than likely that he never saw the jungle-covered plain, bounded by two rivers and, on each of its long sides, by the sea and the hills. Possibly Hutchinson was seriously ill, or if not, he had a strange premonition of death, for on 24 May, at Ovalau, he made his first and apparently his only will, written in his own hand, signed with his usual firmness, and simply headed "My Will".

I hereby Bequeath and give my Soul to God. Amen.

I Bequeath and Will unto Agnes Warden, eldest daughter of James Warden of Sandhurst Victoria all my goods and chattles [sic] and monies which I have or may hereafter have, all monies in the Colonial Bank of Sandhurst and all monies accruing from the sale of any of my effects as my horse, Buggie \& house. Also my Geological Collection of the Gold fields left by me in the Camp Store \& if the same be sold all monies accruing therefrom-also my Violin-Pianoes\& Contra Basso And also my interest in the North Bendigo Gold Co-and also a share of a lease held with Mr. Keeth also of Sandhurst Victoria and also any land which I may hereafter possess in the Fejee Islands known to Mr. Thomas Clark Solicitor of Melbourne . . . and also my Gold Watch....

Hutchinson concluded by appointing two Sandhurst citizens as executors. Hunter and St. John were the witnesses. ${ }^{31}$

Hutchinson is known to have written sadly of his experiences in Fiji to the Bendigo Advertiser. Two letters from Fiji were published in the relevant period. The first, dated 23 May 1861, and published on 5 July, is almost certainly by Hutchinson, although published anonymously. It begins "every man should think twice before he comes here", and should visit the islands before determining to stay. The letter goes on to describe the hot, wet climate and its enervating effects on health, although it "appears to fatten cattle and sheep". It concludes by referring to cowardly natives, who, "when they fire they turn away their heads", and to their probable early extinction (a mistake made by many observers of Australia and the Pacific in this period). The second letter, dated 22 April and published on $9 \mathrm{July}$, is also anonymous, and refers to Hutchinson by name as one of several "Old Bendigonians" present in Fiji, so that, although the style and content are Hutchinsonian, he was possibly not the author. Hutchinson is mentioned as "going to turn squatter if he can find any land ... suitable for sheep". St. John, "trying to make a fortune in land speculations", and Maurice Russell, "the crack publican of Fiji" are amongst others from Bendigo. Much of this letter could well reflect Hutchinson's views, for it records disenchantment and disillusion with the expected romantic concept of an island idyll, a "peaceful home [where] I intended to remain for a year or two, to purify my heart from its thirst after profits and general Australian propensities, and to spend my thoughts amongst the scribes of philosophers of classic lore, and fancy myself in the groves of Academe". The letter concludes with an amusing description of the trial of a native

21 The original will is in the records of the Registrar of Probates, Melbourne; there is a contemporary certified copy in the National Archives of Fiji. Pritchard erroneously reported to London that Hutchinson died intestate, and remitted the balance of the estate ( $£ 210 s .6 d$.$) : PRO, Foreign$ Office, Consular, Pacific Islands, FO 58/94, p. 201 (information provided by Mrs. Alexandra Bremridge, per Dr. E. A. Spriggs). Apparently this sum was insufficient to provide any marker for his grave. 


\section{Bryan Gandevia}

for murder and cannibalism in which the writer has been one of the judges. The accused was convicted on the first charge but not of having eaten his victim, a "mitigating circumstance" which led to a sentence of five years' labour for the Fijian King: "I would sooner be hanged than hang a man, that is my notion of right, and I was very glad the culprit got off as he did"-surely sentiments consistent with Hutchinson's attitudes.

"On or about 16 July", so later documents state, John Hutchinson died. Three months later rumours of his death reached Bendigo, and were confirmed in November on the return of a Sandhurst miner from Fiji. He reported that Hutchinson, like most European visitors, developed dysentery shortly after his arrival. "He fell into a desponding state of mind, and was anxious ... to return to Victoria but there was no vessel to leave by". He was said to have become "very careless of himself and fell into intemperate habits", but the Advertiser commented that although it was impossible to assess to "what state combined effects of disappointment, disease, and the absence of all comforts" may have reduced him, his Sandhurst friends could only regard the report of drunkenness with astonishment or disbelief. The same notice records that "he was buried in the scrub and his grave, noticeable only by the raised mound of earth, is marked by no tombstone and fenced by no railing. There is nothing to show that there lies the man of education and scientific acquirements who had made a name for himself in his profession in the first city of the world". 32

Agnes Warden, Hutchinson's sole beneficiary, and the daughter of a self-styled professor of music, was barely sixteen when Hutchinson left Bendigo. This age is recorded on her marriage six months later on 23 September 1861 to Sigismund Wekey, aged thirty-two, the former secretary of the Philosophical Society. In December 1861, the Victorian Supreme Court granted letters of administration to Agnes Wekey, and subsequently "with the concurrence of her husband", she and Hutchinson's former partners "duly made partition of the land". ${ }^{38}$ In her affidavit she stated that the value of Hutchinson's estate did not exceed $£ 400$. In August 1870, she sold her 5000 acres in the modern district of Tauarau for $£ 400$ : in what Wekey regarded as a miscarriage of justice, a court in Melbourne had obliged him to spend a year in prison, a crisis in which Hutchinson's bequest acquired special value. In the interim, parts of the land, perhaps not Hutchinson's share, were employed in growing cotton; it is now mostly devoted to sugar cane, and no sheep have ever grazed upon it.

\footnotetext{
82 Rumours of his death were mentioned in the Bendigo Advertiser of 1 and 2 October 1861, and the final detailed account appeared on 16 November. There is no death certificate in Victorian court or probate records, and none in the records surviving in London or Fiji. There is also no record of his death in archives relating to the United States Consulate in Fiji. My search of the small cemeteries on Ovalau (two date back to the relevant period) yielded only one identifiable tombstone of the 1860 s in the overgrown and precipitous churchyard of the church of St. Columba. Most of the headstones have long since disappeared from the recently restored graveyard in the old part of Levuka; understandably, there is no prospect of identifying any grave less substantially marked.

sa National Archives of Fiji. Registrar-General's Department British Consul for Fiji and Tonga Register of Deeds, vol. 3, no. 790 et seq. The records of the Lands Commission suggest that the subdivision was made by agreement between the three original owners.
} 


\section{John Hutchinson in Australia and Fiji}

THE ENIGMA OF JOHN HUTCHINSON

The biographical facts concerning Dr. John Hutchinson provide more questions than answers. Why did he forsake a European reputation, an established position as an international consultant, years of meticulous study and research, as well as a wife and family, for practice in a remote colonial township in its rough-and-tumble infancy? The decision to emigrate once taken, his choice of a golden colony is readily understood in view of his mining and geological interests, but why did he avoid publicity, at least medically, and the honour and status which he would have been accorded-indeed, was offered-in Melbourne? Why did this diligent observer in a variety of fields publish nothing in scientific journals after his arrival in Australia at a time when its scientific activities and opportunities were burgeoning?

One can only speculate concerning his motives. The usual reasons for migration of men in Hutchinson's social position at this time were a desire for gold, the cure of tuberculosis, and escape (or banishment) from the domestic scene, or from other conflicts. In view of Hutchinson's success in London, it is unlikely that he elected to follow the hazardous pursuit of gold solely on economic grounds. His delayed entry into medical practice, conceivably precipitated by injudicious mining speculation, may have reduced his resources, but the limited value of his Australian estate does not indicate that he brought great wealth to this country. His will, which ignores his family and any English possessions, suggests that he had provided for wife and children before his departure. Perhaps any hypothesis involving a personal tragedy or domestic discord should take into account the single word "Faithful" enigmatically inscribed on the family gravestone. ${ }^{34}$

Beyond the comedian's veiled allusion noted above, nothing has been found to support the tradition that he undertook the long sea voyage to an allegedly favourable climate because of pulmonary tuberculosis, nor would this view be in accord with a subsequent move to the heat and humidity of Fiji. Hutchinson's friends believed him to be only "about 45 years of age" at his death, implying an appearance of relative youth rather than chronic disease. ${ }^{35}$ There is no evidence for the family tradition that he was killed and eaten by savages during a religious mission to Fiji ;6 his intentions were unequivocally commercial, and the Advertiser's reference to the "shepherd's crook" is not to be taken metaphorically. Hutchinson's departure for Fiji, like his departure for Port Phillip, occurred at a time apparently opportune for investment, although it is difficult to understand why at his age he should seek to turn pastoralist in a distant Pacific island.

A spirit of adventure is often romantically associated with migration to the colonies at this period, but had Hutchinson simply been following his "boyhood's favourite", Captain Cook, he would have turned his steps towards Botany Bay, which he does not seem to have visited..$^{37}$ Nevertheless, he was impressed by "the sublimity of the

\footnotetext{
s Dr. E. A. Spriggs, personal communication. The papers by Spriggs and P. J. Bishop in this issue indicate his earlier successful career.

see note 32 above.

so This fate befell only one missionary in Fiji (Mr. S. Tuinaceva, Archivist, National Archives of Fiji, personal communication).

87 A search of newspapers, archives and indexes in the Mitchell and Dixon Libraries has revealed no trace of Hutchinson in Sydney. His interest in Cook is recorded in his obituary (see note 39 below).
} 


\section{Bryan Gandevia}

enterprise" of Burke and Wills, whom he would like to have joined, ${ }^{38}$ and, if he is accepted as the author of both letters from Fiji, he certainly emerges as a romantic idealist. A less romantic, but more common, association with migration was alcoholism; on the slender evidence of the strange letters to Stawell and others, as well as the disputed observations in his Bendigo obituary, ${ }^{39}$ this cannot be excluded as contributory, although seemingly inconsistent with his earlier career.

Two statements in Hutchinson's London obituary notice deserve comment. ${ }^{40}$ The first is that his geological collection was "destined for the British Museum". It obviously was not, but Hutchinson, by mentioning this possibility to a correspondent in England, may well have given rise to the second observation, that "he was expected to return shortly to his country". There is no evidence that he planned to do this. Fiji in 1861 was even more isolated than Bendigo a decade earlier, and to get from there to England, he would have had to return first to Australia, or perhaps travel via New Zealand or America. It was common and understandable practice to sell one's belongings before any lengthy absence from the Australian colonies, so that the sale of his possessions does not necessarily imply a permanent departure; indeed, initially he offered his house either for sale or lease, and his will indicates some continuing investments.

In the absence of Hutchinson's own reminiscences of "Colonial and Savage Life", 41 the mysteries surrounding his life in the antipodes are unlikely to be resolved. It is difficult, although perhaps an unjustifiable extrapolation, not to sense sadness and loneliness in his later years. Let us hope that his affection for Agnes Wekey, whom he may have known since she was nine or ten years old, was some solace, and that their common bond of music consoled him in any misfortunes which we cannot comprehend.

Taking the romantic view, the Bendigo Advertiser reflected:

How much better in keeping with his reputation and his aspirations it would have been had he died as Burke and Wills died, earning imperishable renown in the service of discovery and science, instead of perishing obscurely and ignobly on one of the savage islands of the Pacific, with his last moments defamed by evil tongues? ${ }^{48}$

\section{ACKNOWLEDGEMENTS}

I am particularly indebted to Dr. Keith Bowden, who made his information on Hutchinson available to me prior to publication of his book, and to Mr. S. Tuinaceva, National Archivist, Suva, Fiji, who made my researches in Fiji a simple matter. My thanks are also due to Miss Ann Tovell, Mrs. Jean Uhl and Mrs. Sheila Simpson for much patient investigation, to Dr. John Gault and the staff of the Advertiser, Bendigo, for local research. The assistance and resources of the La Trobe Library, Melbourne, Mitchell Library, Sydney, National Library, Canberra and the

\footnotetext{
${ }^{28}$ Med. Times Gaz., 22 February 1862, p. 200. This was reprinted almost verbatim in the Bendigo Advertiser 7 May 1862, with the comment that "the memoir will be read with pleasure by his many Sandhurst friends".

20 Bendigo Advertiser, 16 November 1861 (obituary).

10 Med. Times Gaz., op. cit., note 38 above.

11 Ibid.

12 Bendigo Advertiser, op. cit., note 39 above.
} 


\section{John Hutchinson in Australia and Fiji}

Bendigo Regional Library Service (Miss B. Porteous), are gratefully acknowledged.

Copies of documents and of colour photographs of Hutchinson's land, with other material, have been deposited with the Medical Society of Victoria, the Library of the Cardiopulmonary Institute, London, and the Royal Australasian College of Physicians, Sydney.

\section{APPENDIX I}

\section{THE EXAMINATION OF JOHN HUTCHINSON"}

And this deponent upon his oath saith as follows.

I am a member of the Royal College of Surgeons London and a licentiate of the Victoria Medical Board I have examined the remains of the Deceased the same that was viewed by the Jury. It presented the appearance of a male skelleton. The height I believe to be about five feet four inches. I should presume his weight to be about nine stone and a half. There was no flesh on the body except a portion of the scalp (which I now produce) with hair upon it. Aubern coloured hair very light with grey mixed with it. There was flesh also on the left foot below the ankle which ankle and foot had on it a bleu worsted sock with a bit of red thread or worsted in it. The sock was partly drawn off the foot. There was a layer of skin covering the external side of the left leg as high as the knee. This was overgrown with hair as thick as what was seen on the scalp. It was more hairy than any knee I ever saw. The rest of the bones of the body were clean. The bones composing the trunk of the body appeared to be gnawed by animals. Those portions detached appeared much cleaner and had no evidence of being gnawed. As certain bones were broken and certain bones were burnt and certain bones detached I will arraign them as follows First The bones composing the trunk or skelleton eighteen vertebra from the seventh to the twenty-fourth inclusive. These were joined onto the hip bone or pelvis and all the left leg, knee and foot which was flexed and lying outwards. There was the first rib to the ninth inclusive on the left side. The upper half of the right thigh bone was attached to the pelvis. Secondly, bones detached from the body but present as follows Part of the right half of the lower jaw which I now show with four front teeth one molar and the wise tooth. The head with five vertebra which I show together with the broken branches of the lower jaw right and left and the sixth vertebra which was free unattached. The removal of the head from the trunk I am of opinion took place a considerable time after death more than a week. I am of opinion that this was not a wilful act and it might have been caused by the removal of the body. There was also the left blade bone with the collar bone attached also the right blade bone with the upper part of the arm bone or humerus also the lower half of the same bone detached from it. There were also eight ribs belonging to the right side from the third to the tenth inclusive also four anterior parts of the ribs which I now show much burnt. The right leg with foot attached and burnt knee pan. Thirdly. The bones that are wanting as follows. The four front teeth of the upper jaw which I show. The left half of the lower jaw. The left arm and hand The right fore arm and hand and broken portions of the arm bone. The right collar bone. The right lower half of the leg bone or femer except small portions of the internal condyle or head of the knee joint. The last joint of the little toe of the right foot. The three lower ribs on the left side and the two upper and two lower on the right side and the head of the right small bone of the leg. The breast bone and all the anterior portions of the ribs already mentioned as present articulating with the breast bone save the first rib on the left side together with all their cartalages and some pieces of the crest of the right hip bone. Fourth are bones fractured. The head from its crown to its base. The lower jaw into more than three pieces eight ribs on the left side and eight ribs on the right side about the middle of their arch broken inwards. Right arm at its middle. The right thigh at its middle. The marks of fire on the remains of the Deceased are limited. The only mark on the trunk of the body is on the right side of the head behind the ear and about a couple of inches above it. It is completely burnt through at this place. The size of the burn is about two inches in diameter. There are also marks of fire on the fractured ends of the right arm also on the ends of the right fractured thigh bone. On the upper end of the right leg is burnt and head of the small bone of the same leg and downwards a little to the lower end of the shin bone in front and all the right knee pan all the four anterior portions of the ribs found and the right half of the under jaw. The Deceased has received injuries which injuries have been inflicted by a sharp and blunt

12 See note 16 above. 


\section{Bryan Gandevia}

instrument. The sharp instrument has been used to the head and neck. The blunt instrument has been used to fracture the right arm and thigh and the ribs. The first injuries recieved upon the body were recieved on the head during life because of the blood that became extravasated into the scalp and on the bone. There are two wounds on the head which have been inflicted during life. All the other wounds I believe to have been inflicted after death. I believe the person who inflicted the wounds to have stood on the Deceased's left side of his body. I believe them to be inflicted at equal heights. I am convinced of this from the direction of the fractures. There is an anterior and posterior wound on the left side of the head. The anterior is about two inches in length on the scalp it divides the scalp breaking in the frontal bone beneath it to an extent somewhat shorter than the external wound this wound fractures the outer and inner tables of the bone which are depressed. At the lower end of this wound is a fracture which extends across the roof of the orbit on the left eye. From the nature of this wound I believe that the instrument has been sharpened, bevelled on one side and flattened on the other because the wound in the skull shows that the force is not equally in the middle of the fracture. There is a straight edge on the right side of the fracture as you look at it from the left side of the body the other side of the fracture is oval also on the in side of the skull the inner table was detached which portion corresponds to the straight side of the wound from which I deduce that the greatest force has been applied on the straight side of the fracture. The other wound on the skull is on the posterior and upper part of the parietal or wall bone on the same side. This wound is not so long or so deep as the anterior one. This wound however has fractured the skull through both tables which fracture extends upwards with the crown of the skull for two inches and it extends downwards and forwards through the temporal bone in front of the ear into the base of the skull where it runs into another crack which is continuous across the base of the skull ascending upwards through the right temporal bone and in front of the ear on that side and about two inches above the ear as that that fracture extends nearly completely round the skull with the exception of three inches. Both these wounds I have described were inflicted during life. The injuries I am about to speak of now in the base of the skull have been inflicted after death with an instrument of the same kind as I have already described. I believe that the Deceased fell onto his right side after recieving the wounds I have described. Then I believe that his throat has been cut and a sharp chopping instrument employed to divide the head from the back bone. After the head was divided from the vertebrae the blows have been directed by a sharp instrument either an hatchet or an instrument used as an hatchet against the base of the skull shaving off the lower portion of the lower jaw bone on the right hand side then striking across the base of the skull another blow directed on the anterior portion of the mastoid process of the left temporal bone another blow shaved off the mastoid process of the same temporal bone. Another blow posterior to the same mastoid process therefore there is evidence of four blows being given in a similar direction yet no two blows at the precise same spot which accounts for my belief that the instrument employed has been a hatchet or an instrument used as such. After all these injuries the head through the medium of its ligiment of attachment has been retained in its place. I have omitted to draw attention to the left ramus of the lower jaw which shows evidence of a slice being taken off it. The other fractures as the jaw and the right arm and the right leg and all the ribs save the first on the left side have been fractured by a blunt instrument $I$ believe that those fractures as well as the wounds in the base of the skull have been recieved after death because there was no extravasation of blood on the broken ends of the bones showing any marks to have been washed out by exposure to weather. There is no extravasation in the base of the skull nor in the soft parts immediately covering them. I am of opinion that the deceased came by his death from injuries recieved on his head and neck inflicted by some sharp instrument. I have seen the hatchet now produced before. It was after I had formed my opinion as to the nature of the instrument and the character of its edge that inflicted the injuries on the Deceased's head. The hatchet is flat on the right side and bevelled on the left as you would direct its blade to the earth. The anterior blow on the skull described is similarly shaped. As also the wounds about the mastoid process of the temporal bone. I am not prepared to swear that the marks on the hatchet are those of blood. The handle of the hatchet seems to have been scraped I see the hammer portion of the hatchet that would have inflicted the fractures of the arm, thigh, ribs and jaw. I am of opinion that the injuries the Deceased recieved could be inflicted by the hatchet now produced I see the bag now produced with stains on it I am of opinion that they are stains of blood On yesterday I cut off a portion of the bag similarly stained and which I now produce I examined and proved it by six different tests to be blood. I have seen the stain on the right sleeve of the shirt now produced It is situated on its inner side near its risband. It presents all the appearance of blood. With the remains of the Deceased there were some portions of wearing apparel which with the exception of the sock were more or less burnt and in several pieces Those portions of the body which have been broken off such as the right arm and right leg The broken piece of jaw The anterior portion of the ribs and the right knee pan show 


\section{John Hutchinson in Australia and Fiji}

such marks of fire as to lead me to beleive that they were thrown into the fire. When I say that I have discovered blood on the bag I am not prepared to state whether it is human blood or not. The four teeth absent in the upper jaw bone of the Deceased I am of opinion were knocked out after death. The remains shown to the Jury all belonged to the same body. To the best of my opinion the age of the Deceased would be between forty five and fifty years. The Deceased must have been dead for at least seven weeks from the first time I saw his remains. I do not think that he has been dead three months.

Taken and sworn before

JOHN HUTCHINSON* M.D.

me this seventeenth day of

August, A.D. 1858 at the

William Augustine Roche J.P.

Bendigo Hotel Sandhurst

Coroner

*The deposition has been taken by a clerk, but the signature is Hutchinson's; he cannot be held responsible for the spelling and punctuation. 